\title{
Etiologies of 46,XY disorders of sex development (DSD): a collaborative study in Hong Kong
}

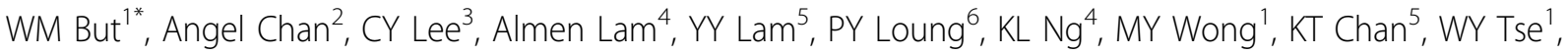 \\ CC Shek ${ }^{2}$
}

\author{
From 7th APPES Biennial Scientific Meeting \\ Nusa Dua, Bali. 14-17 November 2012
}

Disorders of sex development (DSD) are defined as congenital conditions in which development of chromosomal, gonadal or anatomical sex is atypical. In 46, XY DSD, the genotype is $\mathrm{XY}$, but the external genitalia is incompletely virilised, ambiguous, or completely female.

The objectives of this prospective study are to evaluate the testicular Sertoli and Leydig cell functions, to establish the genetic basis and to determine the relative prevalence of etiologies in Chinese patients with 46,XY DSD in Hong Kong. All patients with 46,XY DSD (either new or known) presented to five paediatric departments in Hong Kong from July 2009 till June 2011 were recruited. They were assessed by paediatric endocrinologists. Comprehensive evaluation of testicular and adrenal functions was performed using serum hormonal assays and urine steroid profiling. Based on the hormonal results, mutational analyses of the candidate genes by polymerase chain reaction and direct DNA sequencing were conducted to delineate the genetic basis of the etiologies.

Sixty-five patients (54 male and 11 female) with $46, \mathrm{XY}$ DSD were recruited. Their age ranged from birth to 27 years. Sixty-one (94\%) patients presented with ambiguous external genitalia, two presented with delayed puberty and one each with primary amenorrhoea and inguinal hernia. Definitive diagnoses were made in 25 (38\%) patients. Eleven (17\%) patients had 5-alpha reductase 2 deficiency. Androgen insensitivity was confirmed by genetic analysis in eight (12\%) patients. There was one patient with each of the following etiologies: Swyer syndrome, SF-1 mutation, Frasier syndrome, cholesterol side-chain cleavage deficiency, persistent Mullerian duct syndrome and mixed gonadal dysgenesis. Genetic basis of the etiologies was delineated in 23 (35\%) patients.

\footnotetext{
${ }^{1}$ Department of Paediatrics, Queen Elizabeth Hospital, Kowloon, Hong Kong
}

(c) 2013 But et al; licensee BioMed Central Ltd. This is an Open Access article distributed under the terms of the Creative Commons Attribution License (http://creativecommons.org/licenses/by/2.0), which permits unrestricted use, distribution, and reproduction in any medium, provided the original work is properly cited.
A total of 10 novel mutations were identified. The longest follow up period was 27 years, none of the patients requested change of gender sex so far. In conclusion, 46, $\mathrm{XY}$ DSD is a heterogeneous group with diverse etiologies. Although 5-alpha reductase 2 deficiency is believed to be rare, it is not uncommon in Hong Kong.

\section{Authors' details}

${ }^{1}$ Department of Paediatrics, Queen Elizabeth Hospital, Kowloon, Hong Kong. ${ }^{2}$ Department of Pathology, Queen Elizabeth Hospital, Kowloon, Hong Kong. ${ }^{3}$ Department of Paediatrics, Caritas Medical Centre, Kowloon, Hong Kong. ${ }^{4}$ Department of Paediatrics, United Christian Hospital, Kwun Tong, Hong Kong. ${ }^{5}$ Department of Paediatrics, Kwong Wah Hospital, Yau Ma Tei, Hong Kong. ${ }^{6}$ Department of Paediatrics, Princess Margaret Hospital, Kowloon, Hong Kong.

Published: 3 October 2013

doi:10.1186/1687-9856-2013-S1-P185

Cite this article as: But et al.: Etiologies of $46, \mathrm{XY}$ disorders of sex development (DSD): a collaborative study in Hong Kong. International Journal of Pediatric Endocrinology 2013 2013(Suppl 1):P185.

Submit your next manuscript to BioMed Central and take full advantage of:

- Convenient online submission

- Thorough peer review

- No space constraints or color figure charges

- Immediate publication on acceptance

- Inclusion in PubMed, CAS, Scopus and Google Scholar

- Research which is freely available for redistribution
C Biomed Central 